\title{
Succession Planning and Success in Family-owned Business Enterprise; A Case Study
}

\author{
C. H. Wijayasinghe \\ Central Environmental Authority
}

\begin{abstract}
The authorized and published papers revealed that the persistence of family businesses is controversial in the future. There is empirical evidence to prove the fact that only $30 \%$ of family businesses span to the second generation and that only about $10 \%$ to $15 \%$ survive by the third generation. The major reason for this failure is improper succession planning. The objective of this case story is to identify whether the existing succession process is durable enough to safe guard the future of the well-known Sri Lankan family-owned business called Harischandra Mills PLC. The Company has a long history of over seventy-three years along with a household brand name with quality assurance. While this case focuses on the generational differences and the leadership transformation pattern between the founder and the successors of Harischandra Mills PLC, it also offers some important guidance for the micro and macro perspectives in entrepreneurship. The leadership transformation gaps of Harischandra Mills PLC were explored by the researcher along with safety measures to ensure long-term success, as well as for a smoother transition of the leadership. The success of a family firm depends on its ability to maintain the stability of the business. Hence, it can be said that an effective succession strategy is vital for Harischandra Mills Ltd. to attain a higher level of business performance and to maintain long-term sustainability.
\end{abstract}

Key words: Succession planning, Family-owned business, Harischandra Mills PLC

\section{INTRODUCTION}

Memories of a greater capitalist

$\mathrm{C}$ . A. Harischandra of Matara was a greater industrialist, known to everyone. He was born on $13^{\text {th }}$ of November 1911 and was the fourth son of late Odiris De Silva, a respectable and reputed business magnet in Matara engaged in coconut oil milling. Harischandra had four brothers. He received his primary education at St. Thomas Boys School, Matara and secondary education at Ananda College, Colombo. In 1930 he entered the University College, Colombo and graduated in economics, and he obtained his Inter Commerce degree with credit. After his university education, he came back to Matara and started to run the Broadway Cinema Hall, a bookshop, and a printing press. In 1938 he married to Miss Cornelia Shanthi of Thihagoda, a textile weaving teacher at that time. His charming wife was his own selection and was a tower of strength to him. They had four daughters. Harischandra was a best-known social worker involved in educational, health and philanthropic activities. Harischandra died in 1985 at the age of 74 years.

\section{Evaluation of the business}

More than 80 percent of the world's businesses are family owned. In Sri Lanka, there are well-known family-owned businesses like DSI Samson Group, Hemas Holdings Ltd., Damro Group, Siddhalepa Group, Dilma Group, Maliban Plc., Perera \& Sons and Ceylon Biscuits Ltd etc. and have been ensured their persistence through success. Some of these companies are operated in international soils. Southern Province of Sri Lanka is considered as the ground for family business enterprises. As an example, Harischandra Mills PLC, Nipolac Group, Odiris Silva Company, Rich Curd Company, and Saman Mal Restaurant have widely known family businesses originated in Southern province. However, some of these companies are not continuing at present due to several reasons.

'Harischandra' is a well-known family business which, originated in the district of Matara of the Southern Province, Sri Lanka. Matara is one of the largest cities in Sri Lanka belongs to the low country wet zone. Its population is about 803,999 according to the 2012 Population and Housing Census. Matara is situated between Galle and Hambantota districts. Although there are other ethnic groups, the majority of the people in the district are Sinhala Buddhist. Harischandra is a familial business which has a greater history. Kandaudarata Arachchige Odiris Silva (father of Harischandra) is the founder of the preliminary business, who was born on $2^{\text {nd }}$ August 1867. As his education was disrupted due to some reason, he had started a business for extracting coconut oil by using a Sekkuwa (a grinding machine made out of granite and driven by a bull) belonging to his grandfather Samichchi de Silva. In addition to his oil business, he had run a cinema and a printing press. Although Odiris Silva had five sons and six daughters, Harischandra was the only child (fourth son of the family) who actively involved in his father's businesses. After some time, Harischandra decided to start his own business and as a result, he had started a rice mill with a small capital. With the commencement of the World War II in 1942, he started a timber mill and obtained contracts from the government and the Army to supply rice and timber.

The Harischandra Mill was formed by Harischandra, in 1943, with an initial capital of Rs. $25,000 /-$ on a land area of 20 perches. The Company has a long history over seventy-four years and a household brand name has been born purely base on quality. The Harischandra Company had been started as a small business to supply daily essential food, flour and 
coconut oil for the neighborhood. The company's initial operation was milling of rice, Kurakkan, and other grains. First, a rice mill was started with a small capital at Angarika Dharmapala Mawatha, Matara in 1943. Subsequently, several mills had been started such as mill for timber, rubber, copra, oil, soap and the production of gingelly oil as well. The business had gradually expanded into various other fields including the milling of coconut oil. During the period of 1945 - 1946, the business had been shifted over to No. 11, Delkada Road, Matara, Sri Lanka. Within few years, operations were expanded by adding sawmill and Kurakkan flour mill. Soon the reputation of the company for quality spread far and wide. Then the company formed under the name of the Harischandra Mills (Pvt.) Ltd. in 1953. The company was converted to a Public Quoted Company with limited liability on $14^{\text {th }}$ December 1959 under the name of Harischandra Mills PLC. The Registered Office and the principal place of business of the Company are located at No.11, C. A. Harischandra Mawatha, Matara. In 1983 the company was listed on the Colombo stock exchange. At present, the Harischandra Company is in its third generation.

Table 1: Harischandra product portfolio

\begin{tabular}{|c|c|c|}
\hline Segment & Description & Products \\
\hline Soaps & $\begin{array}{l}\text { Harischandra soap range is gentle on the skin and has no } \\
\text { added animal fat. Harischandra soaps are backed by } \\
\text { generations of trust and are the smart choice for the modern } \\
\text { household. }\end{array}$ & Sal Bar, Senola, Namal, Saman, Aththora \\
\hline Instant products & $\begin{array}{l}\text { Harischandra instant products are the convenient option for } \\
\text { the modern Sri Lankan home. With Harischandra instant } \\
\text { products making delicious and healthy home cooked meals is } \\
\text { simple and quick. }\end{array}$ & $\begin{array}{l}\text { String Hopper flour (Red) } \\
\text { String Hopper flour (White) } \\
\text { Kurakkan Thosai Mix } \\
\text { Hopper /Thosai Mix } \\
\end{array}$ \\
\hline Coffee & $\begin{array}{l}\text { Harischandra coffee has a rich and deep flavor and as it is } \\
\text { made from } 100 \% \text { coffee it produces a pure blend that is } \\
\text { smooth in taste and rich in aroma. Drink a cup of } \\
\text { Harischandra coffee in the morning and it will give you the } \\
\text { perfect start to the day. }\end{array}$ & Harischandra Coffee \\
\hline Flour & $\begin{array}{c}\text { Harischandra flour has been trusted in homes for generations. } \\
\text { With Harischandra flour you are sure of preparing meals that } \\
\text { are of quality and taste. }\end{array}$ & $\begin{array}{c}\text { Rice flour } \\
\text { Ulundu flour } \\
\text { Kurakkan flour }\end{array}$ \\
\hline Noodles & $\begin{array}{l}\text { Harischandra noodles range has been a trusted product for } \\
\text { generations. Turning simple family meals into special events, } \\
\text { Harischandra noodles are the convenient way to preparing } \\
\text { delicious and healthy home cooked meals. }\end{array}$ & $\begin{array}{l}\text { White Rice noodles } \\
\text { Red Rice noodles } \\
\text { Kurakkan noodles } \\
\text { Special/Plain noodles } \\
\end{array}$ \\
\hline Papadam & $\begin{array}{l}\text { has been a favorite accompaniment for generations, with the } \\
\text { young and old alike enjoying the crispy taste. Harischandra } \\
\text { papadam is made from natural ingredients and is packed with } \\
\text { taste and goodness. Fry some Harischandra papadam and } \\
\text { watch the food disappear. }\end{array}$ & $\begin{array}{l}\text { Masala Papadam } \\
\text { Rice papadam } \\
\text { Papadam }\end{array}$ \\
\hline $\begin{array}{l}\text { Pickles / Chutney } \\
\text { / Curry Pastes \& } \\
\text { powders }\end{array}$ & $\begin{array}{l}\text { With its home cooked flavor, natural ingredients and no } \\
\text { artificial preservatives, the Harischandra pickle range is a } \\
\text { convenient and healthy choice for the modern home. Turn } \\
\text { everyday meals into special occasions as Harischandra pickles } \\
\text { enhance the flavor of your dishes. }\end{array}$ & $\begin{array}{l}\text { Date and Lime chutney/ Tamarind } \\
\text { chutney/ Malay /Garlic pickle } \\
\text { Curry paste/ Chilli paste } \\
\text { Turmeric/Chilli powder }\end{array}$ \\
\hline Gingelly rolls & $\begin{array}{l}\text { Harischandra gingerly rolls are legendary and are the perfect } \\
\text { after meal dessert or snack. Jaggery and sesame seeds are } \\
\text { combined to create this local heavenly sweet. }\end{array}$ & Harischandra Gingelly rolls \\
\hline Kithul Treacle & $\begin{array}{l}\text { A staple in all Sri Lankan homes Harischandra Kitul treacle is } \\
\text { made from natural Kitul sap. It is used to make traditional } \\
\text { sweets and is also ideal for curd, ice cream or with freshly } \\
\text { baked bread. }\end{array}$ & Harischandra Kithul Treacle \\
\hline Coconut vinegar & $\begin{array}{l}\text { Harischandra coconut vinegar brings out the natural flavor of } \\
\text { salads made with fresh vegetables. Just a splash of } \\
\text { Harischandra coconut vinegar makes home cooked fish and } \\
\text { meat curry tastier. }\end{array}$ & Harischandra Coconut vinegar \\
\hline Bakery Products & Harischandra produces a wide range of bakery products. & $\begin{array}{c}\text { Bread, Rolls, Biscuits, Buns, Murukku } \\
\text {...etc }\end{array}$ \\
\hline
\end{tabular}

Presently, Harischandra is the market leader for noodles, coffee, Kurakkan flour and Ulundu flour. In addition, the company has an appreciable market share for rice flour, laundry bar soap and blue washing soap. Today, the company offers a wide range of goods (thirty-three brands) as depicted in Table 1, all across Sri Lanka. All the Harischandra brands are fallen under two main marketing segments of food and 
soap. Thus, the principal activity of the company is manufacturing and distribution of food and soap products.

\section{Business model that developed with heritage}

The main objective of the company was to utilize local raw materials and to provide maximum job opportunities to the people in the area. The company has four main corporate objectives namely; a) Constant improvement of the quality of all products b) Provide a fair return to shareholders while safeguarding their investment c) To encourage and promote the manufacture of foodstuffs and maximizing the use of raw materials locally available. d) Provide opportunities for personal and career development of employees with maximum benefits. The company Vision lies down to enhance the heritage brand status and serves the nation. The formulated Mission statement of the company is to provide the public with a variety of high-quality foods and soaps. Both statements reflect the differentiation of strategy and the accountability of enhancing the national heritage brands by means of maintaining the high quality. The company always used indigenous raw materials for its products. Therefore, the farmers in the area got an opportunity to supply required raw materials and they were able to find a market. The company ensures maximum manual operations in the manufacturing/supply/value chain to sales and marketing besides employing the state-of-the-art technologies for the production of bulk products.

During the last ten years, the company has bought some hightech machinery to accelerate the manufacturing process and to minimize the wastage. The company's commercial operations somewhat unique when compared to fully machinery-oriented business models. As competitors more tend to use high-tech modern technology with minimum human resources, the rivalry within the marketing segment is very high. But in the case of Harischandra, it always tries to use maximum human resources during the manufacturing and packaging processes. The company's packaging process is almost done by manually with the intention of providing more employment for the people in the region. Harischandra has always maintained the original quality of their products and therefore the "powderedcoffee" has become the market leader in the coffee marketing segment, Sri Lanka. Harischandra coffee has a precise taste and aroma unique to Sri Lankans. Harischandra is the first manufacturer of noodles in Sri Lanka which has a considerable market share in the food industry. Labour relations are one of the most important elements for the success of its unique production process. Today, the brand name of 'Harischandra' has become highly popular and the products are available island wide. The Harischandra Mills PLC has six key divisions such as finance, marketing, human resource management, quality assurance, production and commercial activities. All the operations of these divisions are performed under one roof. The Company had 935 employees by the end of 2016 .

A trusted name for quality
Supplying of absolutely natural, pure wholesome food for their customers is the utmost intention of the company. For that reason, the company had set forth quality objectives as a) Reduce the reject rate by $2 \%$ every year from the previous year's rejects b) Reduce customer complaints and increase market share by $2 \%$ every year from the previous year's complaints, c) Update equipment and install new equipment to meet the safety and hygienic requirements, d) Utilize $5 \%$ of the net profit of the company to improve environmental hygiene, including adequate handling of factory discharge to prevent pollution of the environment both inside and outside the factory premises. The company has received ISO 9000 in 2001 and ISO 9001 in 2008 for their products by fulfilling quality requirements. Traditional Sri Lankan food is made in a way of combination with love, care, and best ingredients. The quality policy of the company is "to improve the quality of the products constantly and to enhance customer satisfaction towards increasing the market share effectively". The brand 'Harischandra' have earned the respect and appreciation from consumers mainly for the quality of the goods. For over seven decades, 'Harischndra' maintains its market position at a higher level by providing good wholesome food for their loyal customers. The company has a strong and loyal customer base. Those who believe the quality of the product always stands with Harischandra brands. Currently, the company is renowned for its indisputable brands of Harischandra noodles and coffee.

\section{Charismatic attributes of C. A. Harischandra}

Harischandra was born wealthy and therefore he had more chances to grab different types of opportunities. He is not an inventor but he had greater entrepreneurial capabilities to grab the correct market opportunities. He believed that he can work more happily and freely by becoming his own boss and wanted to control business operations by himself. Therefore, he decided to start up a new business without hanging on his father's businesses and he set his own agenda and worked within his boundary. He tried to fulfil the market demand by supplying necessary commodities. Playing a role of a risk taker, Harischandra started the first manufacturing plant of noodles in Sri Lanka. He had a self-motivation to build a profitable business. He preferred a flexible lifestyle but highly committed for his business activities. He knew that those who can perform well can earn much profit. He always tried to find solutions for existing problems. He became the pioneer to start up a new Co-operative hospital in Matara. He had a desire to do something for the community and find solutions to social problems. Those attributes reflect entrepreneurial traits of a social entrepreneur. Although he was not primarily motivated by money, he knew that the profit is not only the factor affecting for the sustainability of the business.

Harischandra had born with the talent for entrepreneurship. He was a graduate in economics and his knowledge had been applied for his business practices. He has not very much believed the luck or supernatural powers, but he always believed the talent and the commitment are coming with the 
success. He always trusted that the company should provide good quality products for its customers. Therefore, he had advised his employees, not to destroy the credibility of the business. He knew that the customer loyalty and the brand equity are the most critical elements to be maintained for household food commodities. He had greater management and employee relation capabilities. He has expertise in business management, accounting, manufacturing and, marketing capabilities as well, in the same area of business. He believed his own ability to meet challenges and had the self-confidence to accomplish whatever the task. Naturally, concerning highquality works, he had a desire to sell only better-quality products.

\section{THEORETICAL FRAMEWORK}

Environmental entrepreneurship widely confers under Schumpeter's Economic Development Theory (Witt 2002; Schumpeter, 1934). According to Schumpeter "entrepreneurs are the innovators that provide the innovation or creative destruction that gives society a new way of addressing problems" (Schumpeter, 1934, p. 66). The original Russian version of the Economic Development Theory was first published in 1911 under the name Theorie der wirtschaftlichen Entwicklung and the first English edition was published in 1934. According to this theory, the entrepreneurship is an engine for economic development which can eventually act as a driving force of destructive innovation (Witt, 2002). Similarly, this theory highlights that environmental innovation could expand the monetary value of a business.

\section{The empirical review of the related literature}

There is empirical evidence to prove the fact that only $30 \%$ of family businesses span to the second generation and that only about $10 \%$ to $15 \%$ survive by the third generation (Beckhard, and Dyer, 1983; Handler \& Kram, 1988; Handler, 1994). Improper succession planning can be severely affected the sustainability of a family firm (Beckhard, and Dyer, 1983). Entrepreneurs strive to reveal potential niche opportunities is a universal assumption. There is a belief that the entrepreneurs are motivated essentially by money (Amit et al., 2001). However, the profit is not the only factor affecting the persistence of a family-owned business. Several scholars (Lankester, 2012; Suess-Reyes, and Fuetsch, 2016) emphasized that the strategies related to sustainability and innovation ensure the long-term survival of a family-owned business. Similarly, Arthur D. Little described 'sustainabilitydriven' innovation based on "the creation of new market space, products and services or processes driven by social, environmental or sustainability issues" Little (2006). The family businesses are required to apply innovative strategies to remain economically sustainable. Diversification considered as one of the most frequently adopted innovation strategies (Schot and Geels, 2008). These strategies couple with the innovative ideas of the successor thus, the innovativeness applied to the business can be changed time to time and generation to generation. The innovation can be motivated by identifying actual needs of the society and exploring creative ways to fulfill those needs (Bickerdyke, Lattomore, and Madge, 2000). Therefore, the persistency of a family business depends upon the ability of the successor to run an innovative business. Many venture capitalists try to keep up their innovative efforts in order to face the competitiveness of the industry. Taneja, Pryor, and Hayek, (2016) have identified the 'innovation' as one of the key drivers of competitive advantage.

\section{Family contribution to run the business}

Harischandra was the Chairman of Haischandra Mills (Pvt.) Ltd. up to May 1985. After the death of Harischandra (1985), Cornelia Harischandra's brother (Mr Jinadasa) had overlooked the business work. After some time, Cornelia Harischandra got the power to run the business. She was the chairperson and the managing directress up to 1989. Harischandra's four daughters (R. K. Samarasinghe, C. P. Rodrigo, N. D. Wijayanandana and M. P. De Silva) and two son-in-laws (F. D. Wiajyanandana and G. S. V. De Silva) were in the director board and they also helped Cornelia Harischandra to run the business. During this period, H. D. Wijayanandana had overlooked the operations in Matara and G. S. V. De Siva had overlooked the operations in Colombo. Cornelia Harischandra passed away in 1989. After her death, the company nominated a new Chairman (E. M. Wijenaike), from outside the family. E. M. Wijenaike held the position of the Chairman, from 1989 to 2005. In 2006, M. A. Bastian (a qualified lawyer) had been nominated as the new chairperson and he was an outside member. In the year 2000, Senaka Samarasinghe, the grandson, the eldest son of the eldest daughter of Harischandra, was elected as the managing director (MD) and up to now, he is holding the position of MD. The present director board consists of family members of second and third generations and also with some other outside members. R. K. Samarasinghe (the eldest daughter of Harischandra), M. P. De Silva (youngest daughter of Harischandra), and Sanath De Silva (son-in-law of Harischandra) are still serving for the company. When considering the period starting from 1943 to 2017, there was a significant diminishing of family contribution in running the business (Figure 1). 
Figure 1: Family Contribution to the Board of Directors

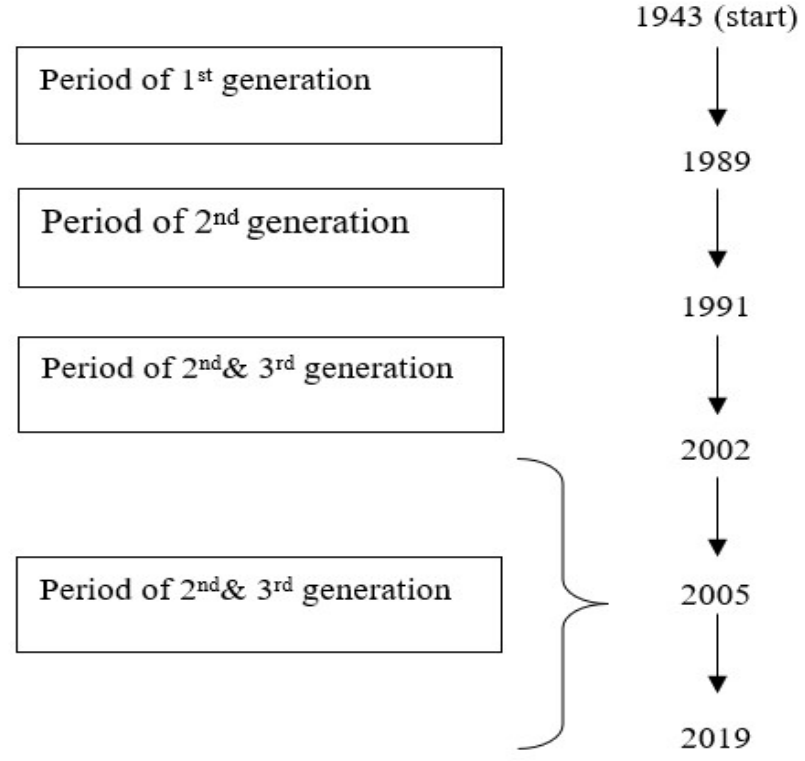

Source: Author's survey, 2019

\section{Transition of the company leadership}

In general, the transition will come from generation to generation. When considering the past period (1943 - to date) of the company, there is a significant diminishing of family contribution in running the business (Figure 2). Further, it can be noticed that the performance of the company had been severely affected by the places of previous leaders' death or retirement has occurred. Therefore, it can be seen a relationship between the succession process and the performance of the company.

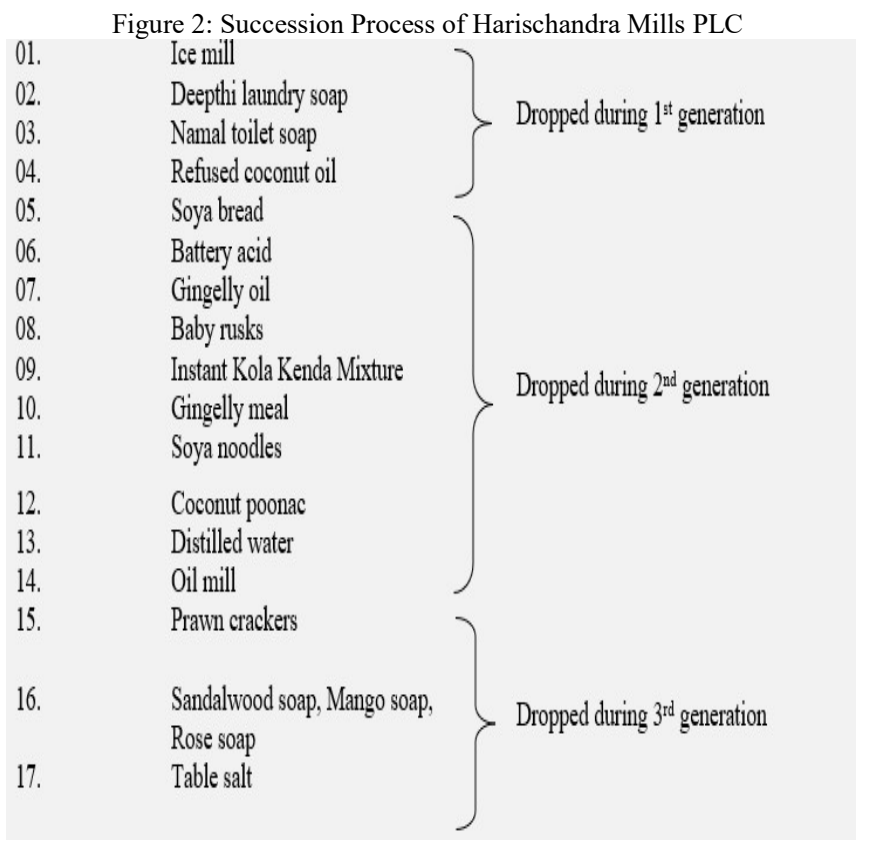

Source: Author's survey, 2019
Total family contribution to the

director board - $100 \%$

Total family contribution to the

director board $-88.88 \%$

Total family contribution to the

director board $-85.7 \%$

Total family contribution to the director board $-66.66 \%$

Total family contribution to the director board $-57 \%$

\section{Warning signs to focus on succession}

The financial performance of a company can be normally measured by using key financial ratios namely; profitability ratios, liquidity ratios, and leverage ratios. For this study, the researcher has used Return on equity (RoE) and Current Asset ratio as they are fairly depicted the financial performance of any business entity. The financial information related to RoE and CA had directly obtained from the archive data of Harischandra Mills PLC (Annual reports, financial statements, sales reports and other publications on company performance).

Profitability of a company is an indicator for increasing the productivity through maximum utilization of available resources to obtain the maximum profit to attain the set goals. On the other hand, the efficiency of the company's operating cycle depicts the liquidity position of the company. The variation of Return on Equity (RoE) and Current Asset (CA) ratio during the transformation of the leadership has shown in Appendix 1. One of the most important profitability matrixes is RoE. The RoE defines as net income available to common stakeholders divided by common stakeholders' equity. It is a measure of the return on total investment in the enterprise. RoE offers a useful signal of the financial success. When considering the past thirty-three years, the company's RoE values have fluctuated throughout the period. A steadily decreases in RoE is a signal of poor performance of a company. Figure 5 clearly shows the variation of the RoE from the year $1982-2016$. 
Figure 3: Variation of Return on Equity during the transformation of the leadership (1982 - 2016)

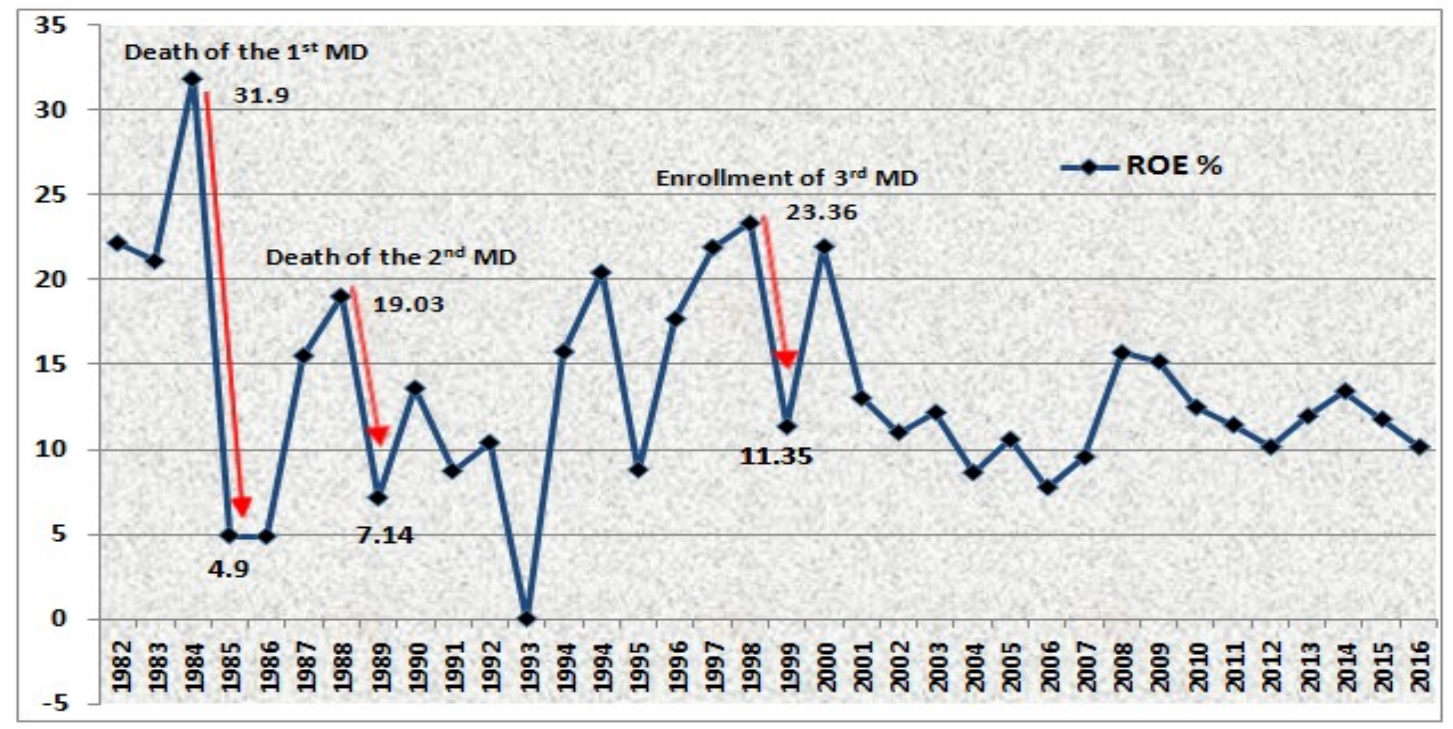

Figure 4: Dropped products from the product line (1943 - to-date)

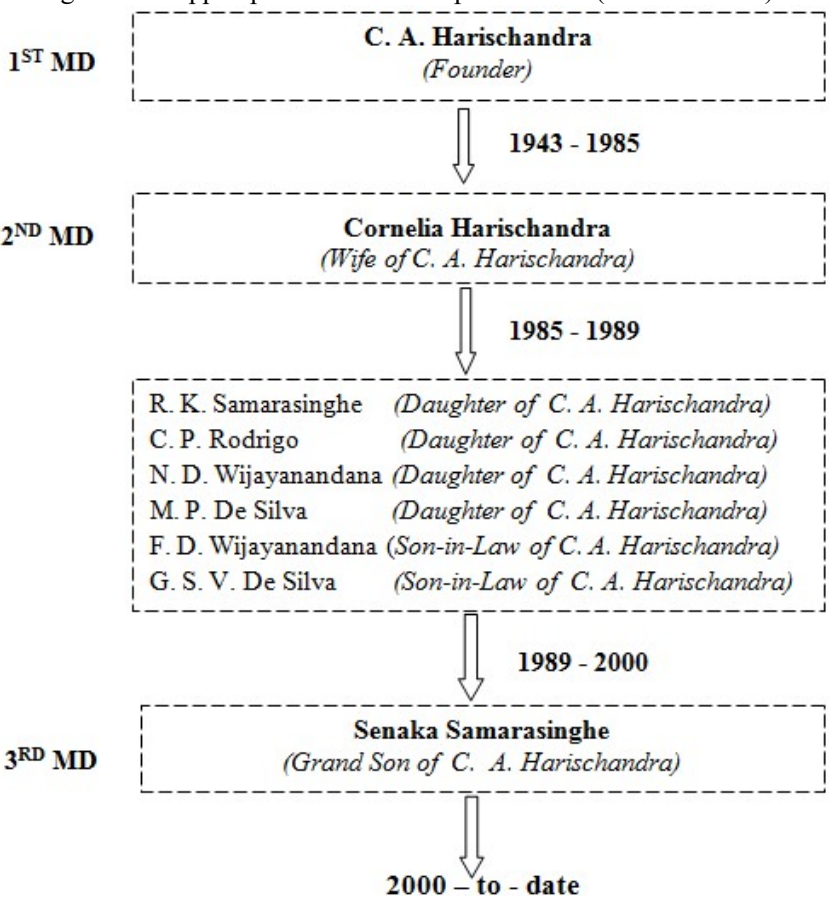

Source: Author's survey, 2019

\section{Backdrop}

Throughout the past period, starting from 1943, some of the culinary items were dropped from the product line of the Harischandra Company, due to several reasons. The company had to close down the oil mill in 2003 due to continued losses. Products which, dropped from the product line have been shown in the Figure 3. During the years 1982 (RoE -22.2\%) and 1983 (RoE-21.13\%), company maintained a high RoE values. Harischandra ( $1^{\text {st }}$ Managing Director $)$ of Harischandra Mills PLC has passed away in 1985 and then the RoE value of that year has drastically dropped from 31.9 percent to (1984) to 4.9 percent (1985). After the death of the $1^{\text {st }} \mathrm{MD}$, Cornelia Harischandra took over the MD position of the company. She was the $2^{\text {nd }} \mathrm{MD}$ of the Harischandra Mills PLC. The RoE value was stable in 1985 (4.9\%) and 1986 (4.85\%) and started to increase gradually and reached to 19.03 percent in 1988 . The $2^{\text {nd }}$ MD's death occurred in 1989 and RoE value dropped from 19.03 percent (1988) to 7.14 percent (1989). Similarly, the oil mill suffered a loss within this period due to declining oil prices and poor-quality 'Copra'. After the death of $2^{\text {nd }} \mathrm{MD}$, the company nominated a new Chairman (E. M. Wijenaike) and a director board consisted of four daughters and two sonin-laws of Harischandra. E. M. Wijenaike is not a member of the family and he held the position of Chairman, from 1989 to 2005. Within the period of 1991 -1992 company introduced a few new products to the market out of which the herbal toilet soap "Aththora" has had encouraging demand. In 1993, the government had increased turnover tax and excise duty by 30 percent and therefore, the company's RoE value had declined up to $-2 \%$.

In addition to that, RoE value was decreased due to low utilization of oil mill and the poor performance of the soap factory. During the year 2003, rising cost of raw materials was affected to the low profitability of the business. However, RoE values had been fluctuated throughout the period of 1990 - 1999 and finally reached the maximum value of 23.36 percent in 1999. Within the period of 1998 - 1999 the company improved its technology and it caused to have an excellent performance of the production of coffee and noodles together. In the year 2000, Senaka Samarasinghe, the grandson of Harischandra, had appointed as the $3^{\text {rd }} \mathrm{MD}$ of the 
Harischandra Mills PLC and during his tenure, the company had obtained the ISO 9002 certificate for the soap segment and RoE values had increased from 11.35 percent (2000) to 21.98 percent (2001). During $2002-2003$, RoE dropped again down from 13.03 percent to 10.99 percent due to the high raw material cost of soap and also the low profits of the oil mill. Within the period of $2003-2004$, the oil mill was closed due to continued losses. This section has made continuous losses from $1999-2003$ and it became increasingly difficult for the company to absorb these losses. During 2004 - 2005, the company's RoE fell down from 12.17 percent 8.63 percent due to the effect of the tragedy comes with the tsunami. But, again starting from 2006 - 2009, the company's RoE percentage increased from 10.58 up to 15.71 due to favorable market conditions. But, again starting from 2010, the RoE values were gradually declined due to sales affected by drought conditions prevailing in the Northern and Eastern areas of the country, as well as low overall demand. The main reason for the decline is due to higher input costs which the company was unable to pass on to the consumer.

As shown in the Exhibit 5, there was a significant drop in return on equity at the point where the transition of leadership had occurred. Family conflicts due to poor succession planning were the major reason for decreasing RoE during this period. When considering the average figures of each MD's era, $1^{\text {st }}$ MD marked the 20.03 percent highest average of RoE value, $3^{\text {rd }}$ MD recorded the average of 12.13 percent RoE value and the $2^{\text {nd }} \mathrm{MD}$ recorded the lowest average of 11.64 percent RoE value. The second highest ratio of 12.13 percent recorded in the period of the second generation, when the daughters and sons-in-law run the business.

\section{Efficiency of the company's operating cycle}

Current Asset (CA) ratio is used in analyzing the efficiency of the company's operating cycle to measure the liquidity position of the company. This ratio also helps to get an idea about the working capital management abilities of each leader. It is said that the companies which have a CA ratio of 2:1 are managing in a favorable position. Companies should have a Current asset ratio of at least 2:1. Graph 2 is shown the variation of the CA ratio in relation to the succession of the company. Accordingly, during the period of $1^{\text {st }}$ MD (19811985) CA ratio managed to maintain within $2: 1-3: 1$. After the demise of C. A. Harischandra in 1985, the CA ratio increased from 3:1 (1985) to 4:1 (1986) within the leadership transition period. After then, during the $2^{\text {nd }}$ MD's period (1986 -1989), CA ratio has remained stable at 4:1.

However, CA ratio has fluctuated throughout the period of the years in-between 1990-1999. When considering the past thirty-four years (1982 - 2016), the company's current asset ratio had fluctuated remarkably in-between $2: 1$ to $4: 1$. During the $3^{\text {rd }}$ MD's period starting from 2000, CA ratio remained stable at 4:1 and again in 2007, the ratio has declined up to $3: 1$. A company with a very high current ratio may be stable in the short term it probably has no means of sustaining its long-term growth and performance. During the period of $1^{\text {st }}$
MD tenure, the CA ratio was at a reasonable level. Due to excess stocks of raw materials and finished goods may be the reason to lead the increase of the $\mathrm{CA}$ ratio during the period of the $2^{\text {nd }}$ and $3^{\text {rd }} \mathrm{MD}$.

Figure 5: Variation of Current Asset Ratio (1982 - 2016)

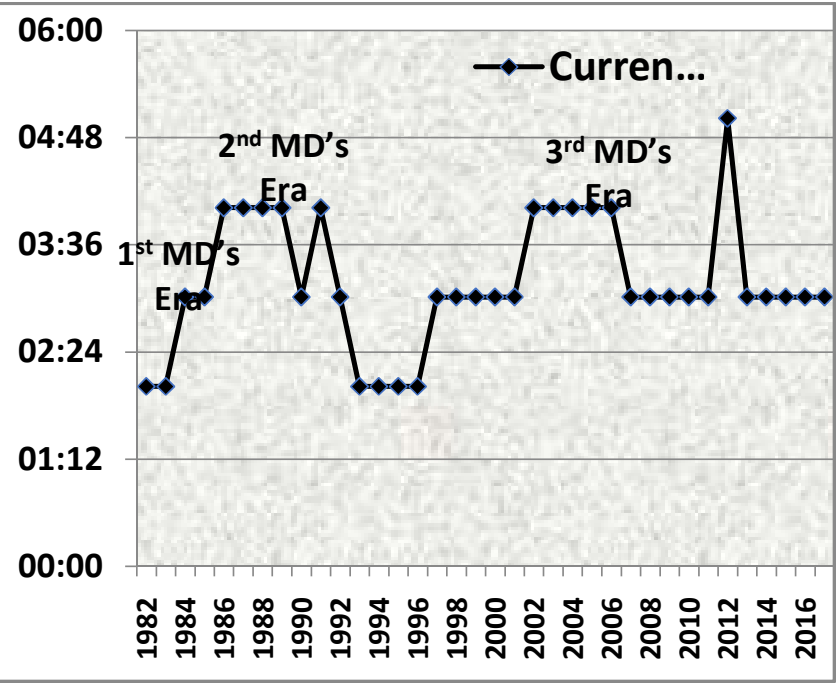

Succession process as a strategic paw

The authorized and published papers revealed that the persistence of family businesses is controversial in future. There is empirical evidence to prove the fact that only $30 \%$ of family businesses span to the second generation and that only about $10 \%$ to $15 \%$ survive by the third generation. The major reason behind this failure is improper succession planning. The ultimate objective of the succession planning is to provide for continuity of business through the transition of ownership and management. Therefore, a proper succession plan is a vital constituent for ensuring the long-term viability of a business. As the founder does not live forever it is the responsibility of the founder to develop a successor. When succession planning is delayed the family members may develop their own sense of expectations. Any postponement of the planning may diminish the success of the business. Normally, founders' desire is to pass the business to a family member. But, if the founder fails to identify a suitable family successor to hand over the business, he or she may transfer the ownership of the business to an outside party.

The founder of the company spent so much time on building and running the business and therefore, he lost the attention in planning the succession process. Due to that reason, members of the next generation were not prepared to take over the business. Any postponement of succession planning diminishes the value of the succession process. At the time of the death of the founder, there was no successor to take over the business, since the succeeding generation was not prepared to take over the leadership. If the owner family has not developed a successor to take up the business after the death or retirement of the incumbent, they will be in a dilemma about the new successor appointment and the 
success after the new appointment. If the family might not nominate a suitable person to take up the business, then it will be the biggest loss in the entire life of the business.

The founder $\left(1^{\text {st }} M D\right)$ and the $2^{\text {nd }} M D$ experienced the difficulties in appointing the next leader of the business as there was no son in the family to take over the business. The founder and his wife $\left(2^{\text {nd }} \mathrm{MD}\right)$ had a risk of transferring the leadership to sun-in-laws. Therefore, there were succession gaps within the company's succession process. When comparing the succession gaps and the business performance of the company, it can be clearly identified that there is a close relationship between these two events. Most of the succession gaps were followed with the performance failures of the business. Business performance of the company had been affected wherever, at the places of leaders' death or retirement has occurred. Family members are responsible for identifying potential successors for their business. It is vital to share the future business strategies and leadership plans with the family members. Deterioration of interpersonal relationships of the family members could destroy the business and create conflicts among the family members.

The $1^{\text {st }}$ MD had run a profitable business, but less emphasis has given on successor development. The $2^{\text {nd }} M D$ also enjoyed strong relationships among family members. The current MD's main concern is to run the business in the most efficient way possible. But he has no clear view on future successors and no plans set so far to develop potential successors. He believes that the other family members in the third generation would not join the company as most of them are now living in aboard. But, some of the family members, who are living in Sri Lanka, may have aspirations to join the business.

\section{CONCLUDING REMARKS}

Although this case focused on the generational differences and the leadership transformation pattern between the founder and the successors of Harischandra Mills PLC, it offers some important guidance for the micro and macro perspectives in entrepreneurship. The researcher has identified the leadership transformation gaps along with safety measures to ensure long-term success, as well as for smoother transition of the leadership. There is theoretical evidence to prove the fact that the people with innovative thinking could wisely discover opportunities from the environment. The scholars have emphasized that the people with a high need for achievement have a strong desire to find a solution to a problem. Thus, it is worthwhile to understand, how the founder of Harischandra Company had brought its brand image up to an elevated level and how the founder's personality traits helped for that achievement. Harischandra has a good reputation for its quality products. Thus, the company can capitalize its brand name to expand the market share.

The Harischandra Company needs a solid succession plan to ensure a long-term success which could provide an undisruptive future. A formalized succession plan will not only establish possible successors but also contribute to the health of the company and avert rivalry among members. The Company should plan the succession process to best fit with the future growth of the business. Top management should take necessary actions to establish a talent pool for all key positions within a firm. Every leader of Harischandra Mills Ltd. is accountable for developing of successors and should have a proper method to identify the strengths, weaknesses, opportunities, and threats that may impact to the company's leadership. Failure of the succession will depend on the owner's specific knowledge on marketing abilities, decisionmaking abilities, performance expertise, and customer relationships which cannot be easily passed on to the next leader. Mr. C. A. Harischandra (founder) had always been maintained close relationships with the employees and with the general public. Hence, the company culture has been developed based on those relationships. However, the company culture had changed under the leadership of the present MD.

Today, most of the family businesses give less priority for grooming future successors, although the succession is the most vital factor for family businesses. If the blood relations are unavailable to take over the business, then the management has to consider an individual who has legally binding relations. If the successor is a family member who has a relationship with the incumbent and the family by blood or by law, then there is a lesser risk of transmitting the leadership. A good business strategy will act as a roadmap to a successful succession plan. Most of the entrepreneurial business models do not consist of a proper succession plan. Therefore, it is difficult to transfer the business to the next generation without any disruption. The high-performing family firms are very much aware of both family and the business dimensions. The success of a family firm depends on its ability to maintain the stability of the business. Hence, it can be said that an effective succession strategy is vital for Harischandra Mills Ltd. to attain a higher level of business performance and to maintain long-term sustainability.

\section{ACKNOWLEDGEMENT}

To Mr. Senaka Samarasinghe, Managing Director of Harichandra Mills PLC, for granting me permission to write a case story on the succession process of the Harischandra Mills PLC.

Appendix 1: Thirty-four years financial summary

\begin{tabular}{|c|c|c|c|}
\hline$\#$ & YEAR & $\begin{array}{c}\text { Return on Equity } \\
\text { Ratio (RoE) }\end{array}$ & $\begin{array}{c}\text { Current Asset } \\
\text { Ratio (CA) }\end{array}$ \\
\hline 01 & 1982 & 22.2 & $2: 1$ \\
\hline 02 & 1983 & 21.13 & $2: 1$ \\
\hline 03 & 1984 & 31.9 & $3: 1$ \\
\hline 04 & 1885 & 4.9 & $3: 1$ \\
\hline 05 & 1986 & 4.85 & $4: 1$ \\
\hline 06 & 1987 & 15.53 & $4: 1$ \\
\hline 07 & 1988 & 19.03 & $4: 1$ \\
\hline
\end{tabular}




\begin{tabular}{|c|c|c|c|}
\hline 08 & 1989 & 7.14 & $4: 1$ \\
\hline 08 & 1990 & 13.6 & $3: 1$ \\
\hline 09 & 1991 & 8.72 & $4: 1$ \\
\hline 10 & 1992 & 10.39 & $3: 1$ \\
\hline 11 & 1993 & $-2 \%$ & $2: 1$ \\
\hline 12 & 1994 & 15.77 & $2: 1$ \\
\hline 13 & 1995 & 20.45 & $2: 1$ \\
\hline 14 & 1996 & 8.79 & $2: 1$ \\
\hline 15 & 1997 & 17.7 & $3: 1$ \\
\hline 16 & 1998 & 21.93 & $3: 1$ \\
\hline 17 & 1999 & 23.36 & $3: 1$ \\
\hline 18 & 2000 & 11.35 & $3: 1$ \\
\hline 19 & 2001 & 21.98 & $3: 1$ \\
\hline 20 & 2002 & 13.03 & $4: 1$ \\
\hline 21 & 2003 & 10.99 & $4: 1$ \\
\hline 22 & 2004 & 12.17 & $4: 1$ \\
\hline 23 & 2005 & 8.63 & $4: 1$ \\
\hline 24 & 2006 & 10.58 & $4: 1$ \\
\hline 25 & 2007 & 7.75 & $3: 1$ \\
\hline 26 & 2008 & 9.54 & $3: 1$ \\
\hline 27 & 2009 & 15.71 & $3: 1$ \\
\hline 28 & 2010 & 15.18 & $3: 1$ \\
\hline 29 & 2011 & 12.48 & $3: 1$ \\
\hline 30 & 2012 & 11.44 & $5: 1$ \\
\hline 31 & 2013 & 10.14 & $3: 1$ \\
\hline 32 & 2014 & 11.96 & $3: 1$ \\
\hline 33 & 2015 & 13.44 & $3: 1$ \\
\hline 34 & 2016 & 11.78 & $3: 1$ \\
\hline
\end{tabular}

[2] Beckhard, R., \& Dyer Jr, W. G. (1983). SMR forum: Managing change in the family firm-Issues and strategies. Sloan Management Review (pre-1986), 24(3), 59.

[3] Bickerdyke, I., Lattimore R. and Madge, A. 2000, Business Failure and Change: AnAustralian Perspective, Productivity Commission Staff Research Paper, AusInfo,Canberra. 50-57.

[4] Handler, W. C. (1994). Succession in family business: A review of the research. Family business review, 7(2), 133-157. doi.org/10.1111/j.1741-6248.1994.00133.x

[5] Handler, W. C., \& Kram, K. E. (1988). Succession in family firms: The problem of resistance. Family business review, 1(4), 361-381.

[6] Lankester, A., 2012. Self-perceived roles in life and achieving sustainability on family farms in North-eastern Australia. Aust. Geogr. 43 (3), $233-251$.

[7] Little, A.D. (2006). The Innovation Highground - Winning tomorrow's Customers Using Sustainability Driven Innovation. Strategic Direction, 22, 35-37.

[8] Schot, J., \& Geels, F. W. (2008). Strategic niche management and sustainable innovation journeys: theory, findings, research agenda, and policy. Technology analysis \& strategic management, 20(5), 537-554. doi: 10.1080/09537320802292651

[9] Schumpeter, J. A., (1934). The Theory of Economic Development. Cambridge, MA: Harvard University Press.

[10] Suess-Reyes, J., \& Fuetsch, E. (2016). The future of family farming: A literature review on innovative, sustainable and succession-oriented strategies. Journal of rural studies, 47, 117140. doi.org/10.1016/j.jrurstud.2016.07.008

[11] Taneja, S., Pryor, M. G., \& Hayek, M. (2016). Leaping innovation barriers to small business longevity. Journal of Business Strategy, 37(3), 44-51. doi.org/10.1108/JBS-12-2014-0145

[12] Witt, U. (2002). How evolutionary is Schumpeter's theory of economic development? Industry and innovation, 9(1-2), 7-22. doi.org/10.1108/EJTD-09-2013-0094

\section{BIBLIOGRAPHY}

[1] Astrachan, J. H., \& Allen, I. E. (2003). MassMutual/Raymond Institute American Family Business Survey.

[2] Harischandra Mills PLC - Financial status; Official web site Thomson Reuters, (2017, June 20), Retrieved from www.ft.com

[3] Harischandra Mills PLC; Official web site, (2017, June 15), Retrieved from http://www.harischandramills.com/

[4] Harischandra Mills PLC; Official web site of the Sunday Times of - January 01, 2012, (2017, June 15), Retrieved from http://www.sundaytimes.lk/120101/BusinessTimes/bt20.html

[5] Hewitt, M. L., van Rensburg, L. J., \& Ukpere, W. I. (2012). A measuring instrument to predict family succession commitment to family business. African Journal of Business Management, 6(49), 11865 .

[6] McClelland, D, C. (1961). The achieving society, New York: Van Nostrand

[1] Amit, R., Mac Crimmon, K. R., Zietsma, C., \& Oesch, J. M. (2001). Does money matter? Wealth attainment as the motive for initiating growth-oriented technology ventures. Journal of business venturing, 16(2), 119-143.

[7] Piyasena, K. H., (2005). Sasiribara Ruhunupura - Harischandra Charithaya, Dhanma Printers 7 Publications, Kalutara, Sri Lanka.

[8] Plans and diagrams prepared for Harischandra Mills PLC; Official web site of the Survey Department of Sri Lanka, (2017, June 23), Retrieved from http://www.survey.gov.lk/ 